Paedagogia Christiana

2/28 (20I I) - ISSN 1505-6872

Stanisław Dziekoński*

Warszawa

\title{
Znaczenie katechezy w edukacji ekologicznej
}

W literaturze naukowej termin „ekologia” pojawił się już w drugiej połowie XIX wieku za sprawą Ernsta Haeckela i był pierwotnie odnoszony do dyscypliny naukowej badającej związki zachodzące w przyrodzie pomiędzy różnymi gatunkami roślin i zwierząt. Wywołane głównie rozwojem przemysłowym groźne zjawiska degradacji środowiska przyrodniczego w skali ogólnoświatowej spowodowały, że w drugiej połowie XX wieku znaczenie tego pojęcia uległo zmianie. Zaczęto je odnosić do wszechstronnych działań na rzecz ochrony przyrody. Zasięg degradacyjnych procesów w środowisku przyrodniczym i ich skomplikowany charakter sprawiały, że w dziedzinę działań ochronnych na rzecz przyrody włączyło się wiele różnych dyscyplin naukowych, przy czym w literaturze dokonuje się rozróżnienia dwóch zasadniczych grup nauk ekologicznych. W skład jednej wchodzą nauki o charakterze techniczno-ekonomicznym, skupiające się na badaniu specjalistycznych aspektów zagrożeń przyrody pod kątem polepszenia jej naturalnego dobrostanu. Drugą grupę tworzą doktryny o orientacji światopoglądowo-filozoficznej, określanej też jako „filozofia ekorozwoju”. Nauki światopoglądowo-filozoficzne prezentują egzystencjalne podejście do badanego przedmiotu, rozpatrując relację człowiek-przyroda w jej istotowych, fundamentalnych strukturach. W zakresie ekologii znaczące miejsce zajmują również idee głoszone przez instytucje religijne zainteresowane tą proble-

* Ks. dr hab. Stanisław Dziekoński, prof. UKSW, dziekan Wydziału Teologicznego na Uniwersytecie Kardynała Stefana Wyszyńskiego w Warszawie, kierownik Katedry Psychologicznych i Pedagogicznych Podstaw Katechetyki. 
matyką, w tym przez Kościół katolicki i jego przedstawicieli ${ }^{1}$. Uwaga ta jest bardzo ważna dla podjęcia niniejszej refleksji skoncentrowanej na znaczeniu katechezy w edukacji ekologicznej.

\section{Racje uzasadniające obecność katechezy w działaniach proekologicznych}

Katecheza jest rzeczywistością obecną w Kościele od samych początków jego istnienia. Jak zauważa ks. Roman Murawski, zajmujący się historią katechezy, w pierwotnym Kościele istniały trzy różne, ściśle ze sobą powiązane i dopełniające się formy głoszenia słowa, które współcześnie oddaje się trzema terminami: ewangelizacja, katecheza, homilia. Ewangelizacja była przepowiadaniem misyjnym, adresowanym do niechrześcijan stawiając sobie za cel ich nawrócenie. Katecheza zmierzała do pogłębienia treści wiary - kerygmatu - u tych, którzy przygotowywali się do przyjęcia chrztu lub u nowo ochrzczonych. Homilia skierowana była do członków wspólnot chrześcijańskich, zgromadzonych na liturgii².

Z biegiem czasu zmieniały się formy i zakres tematyczny katechezy zależnie od różnych okoliczności i potrzeb Kościoła, ale zawsze odnoszono ją do rzeczywistości wiary. W adhortacji apostolskiej o katechizacji w naszych czasach Catechesi tradendae ten związek Jan Paweł II wyraził następująco: „Katecheza jest wychowaniem w wierze dzieci, młodzieży i dorosłych, a obejmuje przede wszystkim nauczanie doktryny chrześcijańskiej przekazywane na ogół w sposób systematyczny i całościowy dla wprowadzenia wierzących w pełnię życia chrześcijańskiego" (CT 18)³.

Katecheza, jakkolwiek jest bezpośrednio związana $\mathrm{z}$ wychowaniem w wierze, obejmuje również swym zasięgiem wiele działań o charakterze ogólnoludzkim, interesując się wszechstronnym rozwojem człowieka. Opinia ta znajduje swe głębsze uzasadnienie w świetle założeń katechezy ukierunkowanej antropologicznie i egzystencjalnie, stawiającej w centrum człowieka i jego życie. Początki katechezy antropologicznej przypadają na pierwszą połowę lat sześćdziesiątych i są związane $\mathrm{z}$ międzynarodowym Kongresem Katechetycznym w Bangkoku (1962 rok), podczas któs. 165.

${ }^{1}$ Por. T. Ślipko, Ekologia, w: B. Szlachta (red.), Stownik społeczny, Kraków 2004,

2 Por. R. Murawski, Stosunek ewangelizacji do katechezy $w$ dziejach katechezy, w: S. Dziekoński (red.), Ewangelizować czy katechizować, Warszawa 2002, s. 15.

3 Adhortacja apostolska o katechizacji w naszych czasach Catechesi tradendae, Rzym 16.10.1979, wydanie polskie w: W. Kubik (red.), Katecheza po Soborze Watykańskim II w świetle dokumentów Kościoła, t. 2, Warszawa 1985 - w tekście CT z odnośnym numerem. 
rego zwrócono uwagę, że w przepowiadaniu trzeba wychodzić od sytuacji człowieka. Katecheza antropologiczna za właściwy cel uznała formowanie dojrzałej postawy wiary katechizowanego z takimi cechami, jak: otwartość na świat, tolerancja wobec innych światopoglądów i wyznań, kontakt z różnymi ludźmi, odpowiedzialność za siebie i innych. W świetle założeń treścią katechezy jest człowiek - jego życie, codzienne doświadczenia, relacje społeczne, twórczość - interpretowane w świetle Objawienia i nauki Kościoła. W antropologicznym modelu katecheza wychodzi od konkretnego człowieka, licząc się z jego rozwojem psychofizycznym, ze środowiskiem naturalnym i społeczno-kulturowym. W jej ramach podejmuje się problemy codziennego życia, kształtując w katechizowanym chrześcijańską postawę otwartości na problemy świata. Model antropologiczny wzbogacił katechezę o spontaniczność, zaangażowanie, twórczość i odpowiedzialność. Katecheza weszła w środowisko świeckie ${ }^{4}$.

Wyjście katechezy ku ludzkim problemom nie musi oznaczać jej sekularyzacji, co mogłoby nastąpić, jeśli katecheza zostałaby sprowadzona jedynie do przekazywania obiektywnych informacji bez ukazania wezwania, jakie stawia Ewangelia przed każdym człowiekiem. Zeświecczenie katechezy jak zauważa ks. Jerzy Bagrowicz - dokonuje się najczęściej pod wpływem zapomniana o zasadzie wierności Bogu i człowiekowi, czyli o zachowaniu wierności Chrystusowi i uwzględnianiu sytuacji katechizowanego ${ }^{5}$. Tymczasem antropologiczne ukierunkowanie katechezy pozwala pełniej zauważyć, że człowiek stworzony przez Boga i powołany do życia wiecznego przychodzi na świat, rozwija się i umiera w środowisku społeczno-przyrodniczym, na które składa się szereg elementów strukturalnych: atmosfera, hydrosfera, litosfera, kosmosfera, biosfera i antroposfera. Środowisko to można rozumieć jako całokształt warunków, czynników, niezbędnych i wystarczających do zaistnienia i rozwoju życia na Ziemi, zarówno w odniesieniu do człowieka, jak i pozostałych bytów ${ }^{6}$.

Zależność człowieka od środowiska jest więc oczywista. Poszanowanie środowiska społeczno-przyrodniczego jawi się jako jeden z podstawowych warunków właściwego rozwoju świata i człowieka, a równocześnie jako ważne zadanie współczesnych propozycji pedagogicznych czy działań wychowawczych realizowanych w różnych płaszczyznach i wymiarach. Wydaje się, że w tym względzie ważną rolę może spełnić katecheza interpretująca

${ }^{4}$ Por. R. Chałupniak, Katechetyka fundamentalna, w: R. Chałupniak, J. Kostorz (red.), Wybrane zagadnienia z katechetyki, Opole 2002, s. 36.

${ }^{5}$ Por. J. Bagrowicz, Edukacja religijna współczesnej młodzieży, Torun 2000, s. 275.

${ }^{6}$ Por. J. M. Dołęga, Stowo o środowisku społeczno-przyrodniczym, w: J. W. Czartoszewski, J. M. Kotowski (red.), Wychowanie do poszanowania środowiska społeczno-przyrodniczego, „Chrześcijaństwo i Edukacja Ekologiczna” 4 (2003), s. 7-11. 
problemy egzystencji ludzkiej i powołanie człowieka w świetle Objawienia i nauki Kościoła.

\section{Biblijne podstawy wychowania ekologicznego $w$ katechezie}

U źródeł katechezy i realizowanego w niej wychowania znajduje się między innymi biblijna prawda o Bogu Stwórcy. W jej świetle początkiem i celem wszystkich rzeczy jest Bóg, który nie ma początku ani końca, stwarza byty z niczego, w sposób wolny i nie potrzebuje przy tym żadnej pomocy, pozostaje wobec stworzenia transcendentny, ale równocześnie podtrzymuje je w istnieniu i nim kieruje oraz pozwala się poznać poprzez stworzone dzieła. Ponieważ człowiek i świat nie mają ani pierwszej zasady życia, ani swego ostatecznego celu, uczestniczą w Bycie samym w sobie. Jemu zawdzięczają swe istnienie i noszą w sobie podobieństwo do Boga. Doskonałość Boga jest wyrażana w prawdzie, dobru, pięknie i harmonii stworzenia, ale jednocześnie poszczególne byty posiadają swoją własną dobroć i doskonałość, trwałość, prawdziwość, własne prawa i porządek. Wszechświat jest ukierunkowany na Boga. Ma w nim miejsce chciana przez Boga współzależność stworzeń, ich solidarność i dokonuje się zbawienie i odkupienie przez Jezusa Chrystusa. Ukoronowaniem wszystkich rzeczy jest człowiek?

Najstarsze refleksje biblijne o człowieku zostały przekazane w dwóch tradycjach Pięcioksięgu, obecnych w Księdze Rodzaju: jahwistycznej (Rdz 2,7) i kapłańskiej (Rdz 1, 26-27). Oba opisy uzupełnia literatura mądrościowa przybliżająca naturę człowieka, którą wyróżniają następujące właściwości: rozumność, wolność, zdolność rozróżniania między dobrem i złem, wyniesienie ponad świat zwierzęcy, tchnienie życia pochodzące wprost od Stwórcy, które jest nie tylko źródłem życia w człowieku, ale wskazuje też na jego szczególną pozycję wśród stworzeń. Człowiek nadaje nazwy zwierzętom, potwierdzając tym samym swą władzę nad nimi. W opowiadaniu biblijnym z tradycji kapłańskiej odmienność człowieka od innych stworzeń została wyrażona $\mathrm{w}$ stwierdzeniu, że w człowieku jest obraz Boży i podobieństwo ${ }^{8}$. Warto podkreślić, że jedynie w odniesieniu do człowieka została zastosowana nazwa „obraz Boży”. Tylko człowiek jest dla Boga „kimś” i został powołany do udziału w Bożych rządach nad światem, do współpracy z Bogiem, do kierowania swoim losem i do odpowiedzialności za swe czyny.

${ }^{7}$ Por. S. Dziekoński, Wychowanie dzieci do poszanowania środowiska ekologicznego jako jedno z katechetycznych zadań rodziców, w: J. M. Dołęga, J. W. Czartoszewski (red.), Edukacja ekologiczna w rodzinie, „Episteme” 9 (2000), s. 236-237.

${ }^{8}$ Por. J. Bagrowicz, dz. cyt., s. 112-113. 
Zaprezentowana w Księdze Rodzaju i powracająca w księgach mądrościowych (Syr 17,3; Mdr 2, 23) idea obrazu Boga, która nadała osobie ludzkiej specjalną, prawie sakralną godność, została pogłębiona i rozszerzona w Nowym Testamencie. Istotnym w tym względzie było objawienie przez Jezusa Chrystusa ojcostwa Bożego oraz naszego nadprzyrodzonego dziecięctwa. W ten sposób wyrażenie „obraz Boży” zostało dopełnione określeniem „syn Boży”, co gruntownie zmieniło nasz stosunek do Boga.

Godność człowieka jako obrazu Bożego, opisana na kartach Biblii, implikuje cztery wymiary powołania ludzkiego: teologiczny, socjalny, kosmiczny i historyczny. Wymiar teologiczny powołania przybliża prawdę, że człowiek jest przeznaczony do dialogu z osobowym Bogiem. Wszystko, co istnieje i dokonuje się, jest apelem Boga skierowanym do człowieka. Odpowiedź człowieka na wezwanie Boże ma się wyrażać nie tylko poprzez praktyki pobożnościowe, ale we wszelkim działaniu podejmowanym przez człowieka, w całym jego istnieniu.

Przy wymiarze socjalnym powołania ludzkiego podkreśla się, że dialog personalny z Bogiem jest ściśle związany z dialogiem wspólnotowym między ludźmi. Zarówno w dziedzinie naturalnej, jak i nadprzyrodzonej nikt nie może autentycznie ubogacać się bez drugiego człowieka. Ktoś, kto wyrzeka się kontaktów z innymi ludźmi, skazuje się na to, że pozostanie człowiekiem niedojrzałym. Człowiek bowiem jest essere sociale, czyli kimś, kto rozwija się i realizuje od początku we wspólnocie, w kontaktach z innymi ludźmi, zapewniającymi jemu ochronę a równocześnie potrzebującymi jego pomocy, świadectwa autentycznej miłości. Nierozdzielna jedność miłości Boga i bliźniego jest jednym z najbardziej charakterystycznych punktów doktryny chrześcijańskiej.

Wymiar kosmiczny powołania oznacza, że świat został stworzony dla człowieka, ze względu na niego, ale też człowiek został powołany do istnienia ze względu na świat. Życie ludzkie - w jego aspekcie kosmicznym - charakteryzuje się zależnością od przyrody, z drugiej jednak strony, przez swą obecność na ziemi człowiek wywiera głęboki wpływ na świat materialny. $Z$ obu opisów stworzenia - jakkolwiek pochodzących z różnych tradycji - wynika, że Bóg nie przekazał człowiekowi świata w doskonałej postaci. Dopiero z nieuporządkowanej ziemi człowiek ma uczynić mieszkanie godne siebie. Osiągnięcie tego celu wymaga współdziałania z Bogiem Stwórcą. Zdobywanie i posiadanie świata żadną miarą nie może przeszkodzić w prowadzeniu dialogu z Bogiem i bliźnimi. Jedynie w ten sposób świat ulegnie przekształceniu od „ziarna” do „owocu”, od potencji do aktualizacji, od niedoskonałości do perfekcji. Tak pojęta „kosmiczna misja” człowieka jest zgodna z chrześcijańską koncepcją świata odkupionego przez Chrystusa i w Nim osiągającego swoją pełnię. 
Wymiar historyczny powołania ludzkiego zwraca uwagę, że oprócz powołania ogólnoludzkiego, realizowanego przez człowieka w ramach misji socjalnej i kosmicznej, istnieje powołanie indywidualne. Bóg zwraca się do każdego człowieka. Nie tylko chrześcijanie, ale każdy człowiek ma swój własny charyzmat $\mathrm{i}$ własną indywidualną misję do spełnienia. Od strony człowieka nie wystarczy jedynie otwarcie się na ten dar Boga, ale potrzebna jest odpowiedź. Jej udzielenie dokonuje się na różnych etapach historii i otrzymuje w ten sposób właściwą sobie specyfikę, zależną od obecnej ekonomii zbawienia ${ }^{9}$.

Pismo święte, obok prawdy o godności i wielkości człowieka, pokazuje nędzę ludzkiego istnienia. Po opisie stworzenia jest przedstawiona prawda o grzechu pierwszych ludzi. Autor biblijny odnosi się do sytuacji człowieka w ogóle i jego ludzkiej kondycji, podkreślając wolną decyzję człowieka skierowaną przeciwko Bogu i ustanowionemu przez Niego porządkowi życia. $\mathrm{Na}$ tę decyzję składają się dwa momenty: pokusa przychodząca z zewnątrz od szatana - i wewnętrzna decyzja człowieka, czyli wybór dokonany w sumieniu. Upadek pierwszych ludzi, chociaż nie zmienił ich cech psychofizycznych, zakłócił jednak do głębi ich stosunek do Boga i ludzi. Wskutek grzechu, odtrącenia miłości Boga, zerwania osobistych z nim związków, człowiek znalazł się w sytuacji, w której własnymi siłami nie jest w stanie sprostać swemu istotnemu przeznaczeniu i jest zdany na przynoszący mu ratunek zbawczy czyn Boga. Uwolnienie człowieka następuje przez mękę, śmierć i zmartwychwstanie Syna Bożego - Jezusa Chrystusa ${ }^{10}$.

Biblijna prawda o grzechu pierworodnym wyjaśniająca, że człowiek ma naturę zranioną, skłonną do błędów i do złego, jest ważna dla tworzenia chrześcijańskiej koncepcji wychowania ukierunkowanego na integralny rozwój człowieka z uwzględnieniem współczesnych uwarunkowań. Zaprzeczenie skutkom grzechu pierworodnego godzi w podstawowe zasady pedagogiki katolickiej ${ }^{11}$, ale też w pewnym sensie znieczula na fakt, że człowiek w swoim nieuporządkowaniu, nie licząc się z Bogiem, zatraca granice swoich relacji do świata przyrody. Rozdarcie i nieporządek moralny w człowieku

${ }^{9}$ Por. M. Filipiak, S. Rumiński, Biblijno-teologiczne ujęcie problematyki antropologicznej, w: A. Hartliński, B. Walczak (red.), Chrześcijańska wizja człowieka, Poznań 1977, s. $80-90$.

${ }^{10}$ Por. J. Bagrowicz, dz. cyt., s. 115-120.

${ }^{11}$ Por. J. Tarnowski, Encyklika Piusa XI „Divini illius Magistri” (1929-1979) wobec ówczesnej pedagogiki chrześcijańskiej, w: L. Balter (red.), Człowiek we wspólnocie Kościoła, Warszawa 1979, s. 384-385. 
mogą spowodować brak ładu w środowisku przyrodniczym. Stąd też jedną $\mathrm{z}$ istotnych kwestii jest formacja sumienia ${ }^{12}$.

\section{Wychowanie ekologiczne $w$ formacji sumienia na katechezie}

U podstaw nauki Kościoła o sumieniu znajduje się przekaz biblijny, potwierdzający powszechnie uznany fakt istnienia sumienia. Sumienie należy do zjawisk codziennych, jego opisy odnajdujemy w literaturze dawnej i współczesnej. W potocznym rozumieniu oznacza ono możność rozróżnienia dobra i zła. W sumieniu widzi się sędziego, będącego w każdym z nas i oceniającego nas samych, przy czym sumienie nie tylko ocenia, ale i nakazuje, dyktuje, co mamy czynić. W kręgu grecko-rzymskiej kultury próby wyjaśnienia sumienia podejmowane były na setki lat przed narodzeniem Chrystusa, o czym świadczą liczne świadectwa, zawierające opisy tego zjawiska w różnych płaszczyznach i przejawach, które odnajdujemy u wielkich filozofów (Sokrates, Platon, Chryzyp z Cylicji, Epiktet, Cycero, Seneka), wybitnych mówców (Demostenes), znakomitych dramaturgów (Ajschylos, Sofokles).

Podstawą refleksji teologicznej dotyczącej sumienia był zawsze przekaz biblijny. Pismo św. nie tylko bezpośrednio daje do zrozumienia, że sumienie istnieje, ale też ukazuje jego charakter i znaczenie w życiu ludzkim. Naukę o sumieniu wypływającą z licznych świadectw biblijnych, zwłaszcza z pism Nowego Testamentu: Ewangelii, Dziejów Apostolskich, Listów św. Pawła, św. Jana Apostoła i św. Jakuba, zauważyli i rozwinęli Ojcowie Kościoła: św. Ignacy Antiocheński, Klemens Aleksandryjski, św. Bazyli, św. Jan Chryzostom, św. Hieronim i św. Augustyn. Nie wypracowano jednak wówczas teorii sumienia.

Znaczniejsze osiągnięcia na tym polu odnotowuje średniowiecze. Myśliciele średniowieczni rozpatrywali sumienie od strony spekulatywnej, chociaż materiał do intelektualnych dociekań brali ze zjawisk obserwowanych w życiu. W XII i XIII wieku jedną z poważniejszych kwestii była możliwość błądzenia sumienia oraz bliższego podmiotu rozpoznania dobra i zła, który zaczęto określać synderezą. Pierwsze poważniejsze wywody na ten temat spotykamy u Filipa, kanclerza Uniwersytetu Paryskiego. W synderezie widzi on równocześnie władzę i sprawność umysłową. W jego ujęciu syndereza nie myli się, natomiast błędy należy przypisać sumieniu.

12 Por. J. Łukomski, Podstawy chrześcijańskiej edukacji sozologicznej w rodzinie, w: J. M. Dołęga, J. W. Czartoszewski (red.), dz. cyt., s. 260. 
Odróżnienie synderezy od sumienia spotykamy w stanowiskach przedstawicieli dwóch wielkich szkół ukształtowanych w średniowieczu: franciszkańskiej, reprezentowanej przez św. Bonawenturę i teologów franciszkańskich, oraz dominikańskiej (tomistycznej), ze św. Tomaszem na czele. Pierwszy kierunek w doktrynie sumienia akcentował aspekt woluntarystyczny. Czynnik wolitywny - uważał św. Bonawentura - występuje już w samym pojęciu synderezy. W tym ujęciu sumienie oznaczało nie tylko akt rozumu, ale też pewną skłonność woli do działania moralnie dobrego. Szkoła dominikańska umieściła synderezę w sferze rozumu. U św. Tomasza syndereza jest wrodzoną sprawnością rozumu praktycznego służącego do poznania pierwszych zasad moralnego postępowania. Posiada ją każdy człowiek, nie może ona błądzić, jest niezniszczalna. Na podłożu synderezy jako sprawności rozumu ujawnia się sumienie, będące sądem orzekającym o prawości działań czy też konkretną regułą postępowania moralnego. W odróżnieniu od synderezy może ono jednak błądzić, przy czym nawet wtedy, gdy jest błędne, zobowiązuje do działania w myśl wskazanej dyrektywy. Oba poglądy były później podtrzymywane przez moralistów, ale większość z nich opowiadała się za rozwiązaniem wypracowanym przez tomistów, zatem za orientacją intelektualistyczną.

Dalekie odejście od niej zaznaczyło się w XX wieku u przedstawicieli filozofii fenomenologicznej, która poważnie wpłynęła na refleksję teologiczną. Według przedstawicieli tego kierunku (Edmund Husserl, Max Scheler) w opisie sumienia należy położyć nacisk na czynnik emocjonalny. W takim ujęciu sumienie przestało być wnioskiem logicznym płynącym z pewnych przesłanek na drodze rozumowania sylogistycznego. Określone natomiast zostało jako przeżycie (akt), i dyspozycja (stałe nastawienie) o strukturze złożonej, w której dominuje nie rozum, ale sfera emocjonalno-wolitywna. W oparciu o zdobycze fenomenologii i psychologii zjawisko sumienia zaczęto ujmować całościowo, dostrzegając w nim udział wszystkich czynników psychicznych. Silnie zarysował się pogląd, że wyjaśnienie istoty sumienia nie jest możliwe bez sięgnięcia do najgłębszej funkcji duszy, do podstawy jedności psychicznej człowieka. Nowy impuls w refleksji teologicznej nad sumieniem dało nauczanie Vaticanum II, w pełni odkrywające religijno-moralny charakter sumienia ${ }^{13}$.

Ojcowie Soboru Watykańskiego II przedstawili definicję sumienia w Konstytucji duszpasterskiej o Kościele w świecie współczesny Gaudium et spes wyjaśniając, że jest ono „najtajniejszym ośrodkiem i sanktuarium człowieka, gdzie przebywa on sam na sam z Bogiem, którego głos w jego

13 Por. S. Olejnik, Teologia moralna fundamentalna, Włocławek 1998, s. 233-243. 
wnętrzu rozbrzmiewa" (KDK 16) ${ }^{14}$. W tym określeniu sumienia zupełnie zanikło podejście intelektualistyczne, charakterystyczne dla teologii scholastycznej, spekulatywnej. Doszło natomiast do głosu ujęcie całkowicie biblijne, gdzie sumienie jest zjawiskiem nie tylko etycznym, ale też ze swej istoty głęboko religijnym ${ }^{15}$. W sumieniu każdy człowiek odczytuje głos Boga, Jego prawo wzywające do miłowania dobra i unikania zła. Posłuszeństwo temu prawu stanowi o godności człowieka. Według tego prawa, odzywającego się w nakazie: czyń to, tamtego unikaj, wypisanego w sercu ludzkim, każdy człowiek będzie sądzony (por. KDK 16).

Niezależnie od różnego podejścia w definiowaniu sumienia, elementem zawsze aktualnym pozostaje jego formacja, która w katechezie dokonuje się zwłaszcza w obrębie wychowania moralnego. Dokumenty katechetyczne stawiają je wśród innych głównych zadań katechezy: rozwijania poznania wiary, formacji liturgicznej, nauczania modlitwy, wychowania do życia wspólnotowego, wprowadzania do misji. Każde z tych zadań ma określoną specyfikę, ale jednocześnie można w nich dostrzec aspekty formacji moralnej, czy też treści, które są bezpośrednio w nią włączone. Katecheza moralna, jakkolwiek jest integralną częścią wychowania do wiary i życia sakramentalnego, uwzględnia też sytuacje ludzkiego życia. Ich analiza, zwłaszcza pod kątem konsekwencji dla pojedynczych osób i społeczeństwa, motywów determinujących decyzje i zachowania osób uczestniczących w danej sytuacji, ma pomóc katechizowanemu w znalezieniu właściwej oceny w sposób wolny i odpowiedzialny.

W wychowaniu moralnym - realizowanym w ramach współczesnej katechezy - jednym z istotnych zadań jest formacja sumienia ekologicznego, czyli wrażliwości i odpowiedzialności za życie w każdej jego postaci: antroposferę, zoosferę, biosferę i geosferę; za cały potencjał genetyczny życia na naszej planecie, za utrzymanie liczebności populacji wszystkich form życia przynajmniej zapewniającej jej przetrwanie w naturalnych warunkach i za nienaruszoną równowagę procesów naturalnych. Współcześnie temu zagadnieniu poświęcają wiele uwagi myśliciele katoliccy, podejmujący temat grzechu ekologicznego bądź też wypracowujący wzorce rachunku sumienia ekologicznego ${ }^{16}$.

${ }^{14}$ Konstytucja duszpasterska o Kościele w świecie współczesnym Gaudium et spes, w: Sobór Watykański II: Konstytucje, dekrety, deklaracje, Poznań 1968 - w tekście KDK $\mathrm{z}$ odnośnym numerem.

${ }^{15}$ Por. S. Olejnik, dz. cyt., s. 242.

16 Termin „sumienie ekologiczne” wprowadził amerykański ekolog-leśnik Aldo Leopold pod koniec lat czterdziestych. W Polsce spopularyzował je Julian Aleksandrowicz. Kształtowanie sumienia ekologicznego jest jednym z zadań edukacji ekologicznej. Por. A. Papuziński, 
W formacji sumienia ekologicznego jedną z istotniejszych kwestii będzie wskazywanie na odpowiedzialność za kształtowanie świata w duchu chrześcijańskim, a więc liczenie się z konsekwencjami przyjęcia prawdy o Bogu Stwórcy i o stworzeniu, która - zgodnie z ogólną instrukcją katechetyczną Directorium Catechisticum Generale z 1971 roku „nie może być przedstawiana zwyczajnie jako prawda samoistna oddzielona od pozostałych, lecz jako prawda rzeczywiście skierowana do zbawienia dokonanego przez Jezusa Chrystusa; stworzenie rzeczy widzialnych i niewidzialnych, świata aniołów, jest początkiem historii zbawienia" (DCG 51) ${ }^{17}$. Zbawcze dzieła Boże osiągną swoją pełnię na końcu świata (DCG 51), zaś „chrześcijanin winien uświadomić sobie z prostotą i szczerością, że ma udział w tym dziele, które mocą Jezusa Chrystusa zmierza ku temu, aby stworzenie uczciło w sposób najwyższy Boga" (DCG 52).

$\mathrm{W}$ formacji sumienia, wpisanej $\mathrm{w}$ wychowanie do poszanowania środowiska naturalnego, duże znaczenie posiada ukształtowanie cnót kardynalnych. Jest to podstawowy warunek osiągnięcia równowagi nie tylko z samym sobą, ale też z bliźnimi i całym otoczeniem - kosmosem. W tym względzie wyjątkowe miejsce należy przyznać roztropności i umiarkowaniu. Roztropność pomaga $\mathrm{w}$ wyborze i zastosowaniu środków do realizacji celów służących stworzeniu optymalnych warunków dla życia ludzkiego toczącego się obecnie i w przyszłości. Uwaga ta jest cenna, jeśli uwzględni się, że aktywność danego pokolenia determinowana jest osiągnięciami poprzedników. Umiarkowanie hamuje nadmierną konsumpcję, która jest przejawem nieuporządkowanego działania pierwotnych popędów ludzkich i przyczynia się do zakłócenia równowagi ekologicznej. Nabycie tej sprawności moralnej jest bardzo ważne, ponieważ współcześnie potrzeby człowieka związane $\mathrm{z}$ egzystencją wywierają coraz większy negatywny wpływ na środowisko naturalne, które jest niszczone przez rabunkową gospodarkę zasobów naturalnych i degradację środowiska. Brak umiarkowania prowadzi do pogardy dla życia ludzkiego oraz wyniszczenia niektórych gatunków zwierząt i roślin. Nieuporządkowana i nadmierna konsumpcja generuje tak zwany efekt cieplarniany. Wychowanie proekologiczne domaga się zatem stosowania zasad etycznych. Właściwa formacja proekologiczna wyklucza wszelki egoizm w użytkowaniu dóbr oferowanych przez naturę i jest ukierunkowana na miłość drugiego człowieka, a także na dobro wspólne ludzkości. Przeciwstawiając się współczesnym zagrożeniom ekologicznym, należy między in-

Edukacja ekologiczna z perspektywy socjalnej kondycji polskiej rodziny, w: J. M. Dołęga, J. W. Czartoszewski (red.), dz. cyt., s. 157-158.

${ }_{17}$ Kongregacja ds. Duchowieństwa, Ogólna instrukcja katechetyczna, 1971, w: W. Kubik (red.), dz. cyt., t. 1 - w tekście DCG z odnośnym numerem. 
nymi wychować człowieka do odpowiedzialności za porządek, który panuje w świecie ${ }^{18}$.

\section{Podstawowe zasady chrześcijańskiej edukacji ekologicznej na katechezie}

Dotychczasowa refleksja pozwala sformułować zasady chrześcijańskiej edukacji ekologicznej prowadzonej w ramach szeroko pojętej katechezy. Pierwsza z nich dotyczy stosowania terminologii religijnej i teologicznej w procesie edukacji. Jeśli środowisko naturalne określimy jako świat stworzony, wówczas akcent zostaje położony na współstworzoność. W tej perspektywie inne stworzenia nie są jedynie czymś zewnętrznym wobec człowieka, ale stanowią integralną część rzeczywistości stworzonej, w której egzystuje też człowiek. Mówiąc o środowisku naturalnym jako stworzonym przez Boga świecie, możemy podkreślać relację Bóg Stwórca-stworzenia, a nie tylko Bóg Stwórca-człowiek. W edukacji ekologicznej stosującej terminologię religijną i teologiczną bezpośrednio wprowadza się wychowanka w odpowiedzialność za inne stworzenia i uczy się bycia z nimi.

Inną zasadą jest zachowywanie perspektywy biblijnej i teologicznej w przekazywaniu treści. Stosowanie tej zasady pozwoli odkryć, że w Piśmie świętym, w nauczaniu Kościoła i refleksji teologów rzeczywistość traktuje się integralnie. Istotne jest zatem, aby w przekazywaniu treści unikać wybiórczego podejścia.

Kolejna zasada dotyczy przekładania treści religijnych (teologicznych), przekazywanych w procesie edukacji, na język praktyki. Katecheza kształtuje w wychowanku najpiękniejsze cnoty chrześcijańskie, wśród których na pierwszym miejscu jest miłość. Autentyczne życie miłością daje najtrwalszą podstawę zaangażowania $\mathrm{w}$ ochronę stworzonego świata i odpowiedzialne nim zarządzanie, które nie polega jedynie na samoograniczaniu, ale prowadzi do wyczulenia na potrzeby drugich, w tym świata zewnętrznego i dąży do mądrego ich zaspokojenia ${ }^{19}$.

Jedną $\mathrm{z}$ istotnych kwestii jest też prowadzenie edukacji ekologicznej w możliwie wszystkich środowiskach, zwłaszcza w tych, które dla katechezy uznawane są za podstawowe: rodzinie, parafii, szkole. Jest to istotne ze względu na skuteczność wychowania, jak też z uwagi na fakt, że każde

${ }^{18}$ Por. S. Dziekoński, Wychowanie dzieci, s. 239-240.

19 Szerzej na temat zasad edukacji ekologicznej w chrześcijańskim wychowaniu pisze J. Leśniewska. Por. Zasady chrześcijańskiej edukacji ekologicznej w rodzinie, w: J. M. Dołęga, J. W. Czartoszewski (red.), dz. cyt., s. 189-214. 
z wyróżnionych środowisk posiada swoją specyfikę. Rodzina w swym pierwotnym znaczeniu wskazuje na rzeczywistość, w której rodzi się człowiek, przy czym zapewnienie ciągłości biologicznej nie jest jedynym celem, ale też przekazywanie dziedzictwa kulturowego następnym pokoleniom ${ }^{20}$. Ze względu na swe naturalne walory rodzina stanowi niezastąpione i najbardziej skuteczne środowisko wychowania z punktu widzenia etyczno-religijnego, psychologicznego i socjologicznego ${ }^{21}$. Nie dziwi więc, że bardzo silnie akcentuje się znaczącą rolę rodziny w katechezie. Opina ta znajduje swoje potwierdzenie między innymi w pierwszym katechetycznym dokumencie Kościoła, jaki ukazał się po Vaticanum II, w ogólnej instrukcja katechetycznej Directorium Catechisticum Generale. Dokument ten wprost wyjaśnił, że ,początki życia religijnego i moralnego sięgają samych początków życia ludzkiego. W rodzinach pierwsze miesiące i lata życia, mające wielkie znaczenie dla równowagi umysłowej przyszłego człowieka, warunkują także chrześcijańską osobowość [...]. Dziecko bowiem przez proces swego rodzaju «osmozy» przejmuje sposób postępowania i myślenia swoich domowników. Stąd w dziecku jakby gromadzi się zespół doświadczeń (doznań). Stanie się on jakimś fundamentem dla jego życia religijnego, które będzie się powoli rozwijało i ujawniało" (DCG 78). W Directorium Catechisticum Generale uwypuklono też pierwszorzędne znaczenie rodziny w formacji sumienia moralnego u dziecka ${ }^{22}$. Nie dziwi więc, że także w wychowaniu ekologicznym dziecka rodzinie przypisuje się znaczącą rolę. Zdrowa moralnie rodzina jest podstawową komórką ekologii ludzkiej. W takiej rodzinie dziecko uczy się szacunku dla bliźniego i przyrody, którą - dzięki rodzicom - może poznawać jako przedmiot podziwu, kontemplacji i traktować ją jako zwierciadło świata, w którym odbija się Przymierze Boga ze stworzeniem. Rozwiązanie przez społeczeństwa kwestii ekologicznej w znacznej mierze zależy od tego, na ile w samej rodzinie zostanie przezwyciężony duch hedonizmu i konsumizmu na rzecz zaangażowania się w tworzenie klimatu ofiarnej miłości. Nie bez znaczenia jest w tym względzie kształtowanie umiejętności gospodarowania skromnymi środkami budżetu rodzinnego i przykład działań proekologicznych rodziców. Do nich też należy umiejętne stawianie dzieciom wymagań i wdrażanie ich do zachowania umiaru w dziedzinie wszelkiej konsumpcji. Chodzi o wychowanie człowieka, który kieruje się zasadą pierwszeństwa

${ }^{20}$ Por. B. Mierzwiński, Istotna rola mężczyzny we wspólnocie życia rodzinnego, Wrocław 1988, s. 132; J. Stala, Wspótpraca środowisk w postudze katechetycznej, w: S. Kulpaczyński (red.), Miejsca katechezy: rodzina, parafia, szkoła, Lublin 2005, s. 142.

${ }^{21}$ Por. M. Strzelec, Wpływ rodziny na religijność dzieci, „Katecheta” 1 (1996), s. 12; Z. Marek, Rodzina i wychowanie, „Katecheta” 3 (1996), s. 134-135.

${ }^{22}$ Por. DCG. Dodatek: Pierwsza spowiedź i Komunia święta, 2. 
„być” przed „mieć”, a przekroczenia wobec środowiska naturalnego umie oceniać w kategorii grzechu ${ }^{23}$.

Edukacja ekologiczna jest ważnym zadaniem szkoły, której stawia się za cel troskę o wielostronny czy integralny rozwój ucznia. W ramach edukacji ekologicznej szkoła ma pomagać uczniowi w nabywaniu i rozwijaniu różnorodnych i potrzebnych w codziennym życiu umiejętności. Uwzględnia się fakt, że poznawanie przyrody jest fascynujące zwłaszcza dla dzieci, stąd też często przeradza się w przygodę życia i trwałe przyrodnicze zainteresowania poznawcze. W ramach szkolnej edukacji przyrodniczej uczeń uczy się o bioróżnorodności organizmów żywych i procesów życiowych, jak też poznaje złożoność zjawisk przyrodniczych. Chodzi przede wszystkim o wykształcenie człowieka samodzielnego, mądrego i odpowiedzialnego za przyrodniczo-kulturalne środowisko życia ${ }^{24}$.

$\mathrm{W}$ ramach wychowania ekologicznego jeszcze inne funkcje spełnia parafia, która w katechezie jest postrzega jako miejsce inicjacji chrześcijańskiej, dokonującej się między innymi przez liturgię. W świetle nauki Kościoła liturgia spełnia rolę wychowawczą, między innymi poprzez symbole zapożyczone ze świata przyrody, takie jak: woda, ogien, chleb, wino, olej i sól. Woda przypomina o czystości, o potrzebie zaspakajania podstawowych ludzkich pragnień, jak też symbolizuje dar Boży. Używana jest podczas chrztu świętego i wszelkiego rodzaju poświęceń. Ogień wskazuje na światło Bożej nauki, żar miłości Boga do człowieka i człowieka do Boga. Przypomina o konieczności strzeżenia płomienia wiary i głoszenia Ewangelii innym ludziom. Jest on obecny podczas wszystkich obrzędów liturgicznych. Symbolika ognia i wody szczególnie silnie jest uwyraźniona w Wielką Sobotę podczas Wigilii Paschalnej, która rozpoczyna się od poświęcenia ognia. Z kolei chleb, wino, olej, sól, będąc pierwszymi produktami otrzymanymi z natury, służą najczęściej jako materia do udzielania sakramentów.

Centrum liturgii jest msza święta, podczas której, obok symboli, pojawiają się teksty modlitw przypominających elementarną prawdę o Bogu, Stwórcy całego świata ${ }^{25}$. Kwestie problematyki ekologicznej można też dostrzec przy analizie obrzędów błogosławieństw dostosowanych do zwyczajów diecezji polskich, wydanych drukiem w 1994 roku. W polskiej pobożności ludowej od wieków pielęgnowane są elementy przyrodnicze. Nazwy wielu obchodzonych w Polsce świąt kościelnych, związanych zwłaszcza

${ }^{23}$ Por. J. Łukomski, art. cyt., s. 274-276.

${ }^{24}$ Por. L. Nowak, Wspótpraca rodziny i szkoty w zakresie edukacji ekologicznej, w: J. M. Dołęga, J. W. Czartoszewski (red.), dz. cyt., s. 277-278.

${ }_{25}$ Por. M. Ostrowski, Motywy przyrodnicze w roku liturgicznym - szanse proekologicznego wychowania, w: A. Dyduch-Falniowska (red.), Stworzyciel i przyroda w tradycji i myśli europejskiej. Dydaktyka chrześcijańskiej etyki ekologicznej, Kraków 1999, s. 99-101. 
z pracą na roli, są świadectwem łączenia życia i pracy z działaniem Boga i Matki Najświętszej. Liturgia świąt: Matki Bożej Śnieżnej, Gromnicznej, Kwietnej, Zielnej, Żniwnej i Siewnej, uwrażliwia na piękno przyrody, która jest równocześnie ukazywana jako dar Boga. Warto podkreślić, że wiele celebracji, związanych na przykład z poświęceniem pól, odbywa się poza świątynią, wśród przyrody i dzieł dokonanych przez człowieka. W modlitwach i prośbach akcent jest położony na odpowiedzialność człowieka za środowisko przyrodnicze i ludzkie.

Analizując znaczenie liturgii w wychowaniu do poszanowania środowiska przyrodniczego, nie sposób pominąć roli modlitwy, przez którą człowiek, zwracając się do Boga, może głębiej pojąć i poznać Go jako początek i koniec wszystkich rzeczy, Pana historii, Jedynego Stwórcę człowieka i świata, objawiającego się w rzeczach stworzonych. Modlitwa, jakkolwiek bezpośrednio odnosi człowieka do Boga, zwraca uwagę na otaczający nas świat przyrody, budząc szacunek i podziw dla dostrzegalnego w nim piękna i harmonii ${ }^{26}$.

\section{Wnioski}

Kwestie ekologiczne są dzisiaj podnoszone często i w różnym kontekście, także w odniesieniu do szeroko pojętej edukacji, w której uczestniczy także Kościół, zwłaszcza poprzez katechezę. W niniejszej refleksji zostały zaprezentowane argumenty najbardziej przemawiające za obecnością katechezy w wychowaniu ekologicznym. Więcej treści poświęcono wybranym zadaniom, jakie podejmuje katecheza, ważnym dla wychowania ekologicznego. Za istotne uznać też trzeba zaprezentowanie zasad chrześcijańskiej edukacji ekologicznej realizowanych w ramach katechezy.

W świetle podjętej refleksji dostrzega się wyraźnie, że katecheza stanowi wyjątkowe miejsce dla edukacji ekologicznej, między innymi dlatego, że daje jej podstawy aksjologiczne. Troska o środowisko przyrodnicze nie jest uzasadniana jedynie argumentami rozumowymi, ale uwzględnia też wymiar religijny. Dzięki religijnej perspektywie, istotnej dla katechezy, uwidacznia się też głębszy sens troski o otaczającą człowieka rzeczywistość, jak też odpowiednia hierarchia wartości. Problematyka ekologiczna jest integralnie włączona w najważniejsze prawdy religijne przekazywane w ramach katechezy, realizowanej w różnych środowiskach, głównie zaś w rodzinie, parafii i szkole. Wydaje się, że ze względu na zmiany dokonujące się pod

${ }^{26}$ Por. S. Dziekoński, Wychowanie ekologiczne w religii chrześcijańskiej, w: J. M. Dołęga (red.), Podstawy kultury ekologicznej, „Zeszyty Naukowe PAN” 32 (2002), s. 67. 
wpływem gwałtownego rozwoju mediów elektronicznych więcej uwagi należałoby poświęcić ich wykorzystaniu w katechezie podejmującej problematykę ekologiczną.

\section{The Importance of Catechesis in Environmental Education (Summary)}

Nowadays ecological problems are frequently addressed and in various contexts, also with reference to education in a broader sense. The Church participates in the education, especially through catechesis. This reflection presents the strongest arguments for the participation of the atechesis in the ecological education. More attention is given to some chosen missions undertaken by the catechesis which are important for the ecological education. The presentation of the principles of Christian ecological education discussed within the catechesis is also of great importance.

In the light of the reflection undertaken it can be clearly seen that the catechesis constitutes a unique space for the ecological education. One of the reasons is the fact that it provides the education with axiological foundations. The concern for the environment is justified by scientific reasons, but it also has a religious dimension. This religious perspective, which is important for catechesis, displays the underlying sense of the concern for the environment as well as the right hierarchy of values. The problems of ecology are inherently related to the most important religious truths spread within the catechesis in various groups, especially in families, parishes, and schools. In the view of the changes connected with a rapid development of electronic media it seems reasonable to state that the catechesis related to ecological problems should embrace the opportunities presented by the media. 